癌化学療法による宿主造血能抑制の

防止に関する基礎的研究

\author{
第 2 編 \\ 諸種免疫賦活郕 [Bestatin, 溶連菌製剤 OK-432, 有機化合物 \\ Carboxyethylgermanium Sesquioxide $(\mathrm{Ge}-132)]$ にる \\ 造血能賦活効果の比較検討
}

岡山大学医学部第 2 内科（主任：木村郁郎教授）

内田耕三郎

(昭和62年 1 月 23 日受稿)

\begin{abstract}
Key words : Bestatin
Myelosuppression by cancer chemotherapy

Hemopoietic potentials of immunomodulators
\end{abstract}

\begin{abstract}
腥
言

癌化学療法の施行に際して認められる造血能 抑制は, 主に感染症, 出血に代表される極力て 急性期的問題と寛解後比較的長期に亘って継続 される維持・強化療法への耐容性といった慢性 期的問題の二つを臨床上提起するものであり, 現在前者に対する具体的方策として clean wall unit の導入など環境管理の改善 ${ }^{1)}$ あるいは非吸 収性抗生物質の予防的投与 ${ }^{2)}$ といった面からの 検討が、そしてまたこれら二つの問題を包括し た対策として各種造血賦活郕の臨床導入 ${ }^{3-5)}$ が 検討されている．すでに著者は本研究第 1 編に おいて免疫賦活郕の一つである Bestatin, [3-(R) -amino-2 -(S)-hydroxy-4 - phenylbutanoyl(S)-leucine] が cyclophosphamide (CPA) 誘発 造血抑制からの回復過程を有意に促進させるこ と,さらに放射線照射後のマウスautologous CFUs を有意に増加させることを明らかにしたが，こ れら二つの実験系は化学療法, 放射線療法によ り薏起された造血障害に対する影響を単一個体 で, 幹細胞動態をふくめ観察し得る点で評価し
\end{abstract}

得る実験系ではないかと考えられた。

さて、これまで各種免疫賦活鼡が開発され， その造血能賦活作用が注目されているが,これ までみられる多くの検討6 -8) はこれら免疫賦活剛 の有す多面的生物学的活性の一つを明らかにす ることを主目的としたものであり，癌化学療法 あるいは放射線療法下での影響さらに各薬剮間 での比較を目的とした体系的な前臨床試験は少 ないようである.また各種薬侴の臨床導入はそ の効果の優劣はもとより，投与方法における簡 便性といった面からも検討・評価される必要が あり，慢性期的造血障害が社会復帰中での寛解 維持・強化療法中に問題となることを考虑した 際，この時期での薬剤投与は静脈内あるいは筋 肉内の連日投与よりも経口投与が至適と考えら れ，投与ルートにそった薬剤の選択も臨床上重 要な問題の一つと考えられる.

今回著者は以上の観点にたち，主に細菌由来 の免疫倵活羭である溶連菌製郕 OK-432（筋注， 静注投与) と化学合成物質である Bestatin（経 口投与), 水溶性有機化合物である Carboxyethylgermanium Sesquioxyde (Ge-132) (静注, 
経口投与) の 3 剂について CPA 誘発造血抑制 への影響，マウス autologous CFUs への影響 を比較検討し，癌化学療法下での造血抑制の防 止, 特に維持・強化療法施行中にみられる慢性 期的造血抑制の防止に対する一助とせんとした.

\section{実験材料並びに実験方法}

実験動物：岡山大学医学部附属マウスコロニ 一にて継代飼育された生後14週, 体重 $24 〜 26 \mathrm{~g}$ の $\mathrm{C}_{57} \mathrm{BL}$ ，雌ハツカネズミを用いた。

薬剤：Bestatin, Lentinan, Ge-132 は各々 日本化薬 K.K. (東京), 森下製薬 K.K. (大阪), 浅 井ゲルマニウム研究所（東京）より供与された ものを用い，実験每に生理的食塩水（生食水） にて至適濃度に稀釈調整し，無菌的に用いた。 また, OK-432, cyclophosphamide (CPA), は 各々市販されているものを用い，実験每に生食 水にて溶解後適濃度に調整し, 無菌的に使用し た.

CPA 誘発造血抑制からの回復過程に及ぼす影 響：本研究第 1 編と同様の方法にて検討した. すなわち薬㓣投与群, 生食水群とも各々 5 匹で 構成し，まず前者には各薬剤の血液所見に影響 を及ぼさない最大投与量 (Bestatin : $0.05 \mathrm{mg}$ / $\mathrm{kg} / 0.2 \mathrm{ml}, \mathrm{OK}-432: 40 \mathrm{KE} / \mathrm{kg} / 0.2 \mathrm{ml}^{22)}, \mathrm{Ge}^{-}$ $132: 40 \mathrm{mg} / \mathrm{kg} / 0.2 \mathrm{ml}$ ) を，後者には生食水 0.2 $\mathrm{ml}$ を一day 5 からーday 1 までの 5 日間連日腹 腔内 (i.p.) に投与, ついで day 0 に各群に対し $\mathrm{CPA} 300 \mathrm{mg} / \mathrm{kg} / 0.2 \mathrm{ml}$ をi.p. 1 回投与し，そ の後の末梢白血球数の変動を day $0,3,5$, 7,9に検討した. 尚, 各薬郕の CPA 誘発造 血抑制からの回復過程に及ぼす影響の比較に際 しては，薬風投与前の白血球数に対する比率を 経時的に算出し，比較検討した。また，骨髄有 核細胞数 (NCC) に対する影響については，薬 剤投与群, 生食水群とも各々15匹で構成し，一 day 5 から-day 1 の 5 日間薬㓮（Bestatin： $0.05 \mathrm{mg} / \mathrm{kg} / 0.2 \mathrm{ml}, \mathrm{OK}-432: 40 \mathrm{KE} / \mathrm{kg} / 0.2 \mathrm{ml}$, $\mathrm{Ge}-132: 40 \mathrm{mg} / \mathrm{kg} / 0.2 \mathrm{ml}$ ) あるいは生食水 0.2 $\mathrm{ml}$ i.p. 投与, ついでday 0 にCPA $300 \mathrm{mg} /$ $\mathrm{kg} / 0.2 \mathrm{ml}$ 者回投与ののち day $0,3,5,7$, 9 に各群 3 匹ずつ屠殺し NCC 算定と骨髄細胞 分類を行った.

マウス autologous CFUsに及ぼす影響：薬 郕投与群，生食水群とも各々 5 匹で構成し，放 射線照射 24 時間前に前者には薬郕 [Bestatin： $0.05 \mathrm{mg} / \mathrm{kg} / 0.2 \mathrm{ml}, \mathrm{OK}-432: 40 \mathrm{KE} / \mathrm{kg} / 0.2$ $\mathrm{ml}, \mathrm{Ge}-132: 40 \mathrm{mg} / \mathrm{kg} / 0.2 \mathrm{ml}$, Lentinan（抗
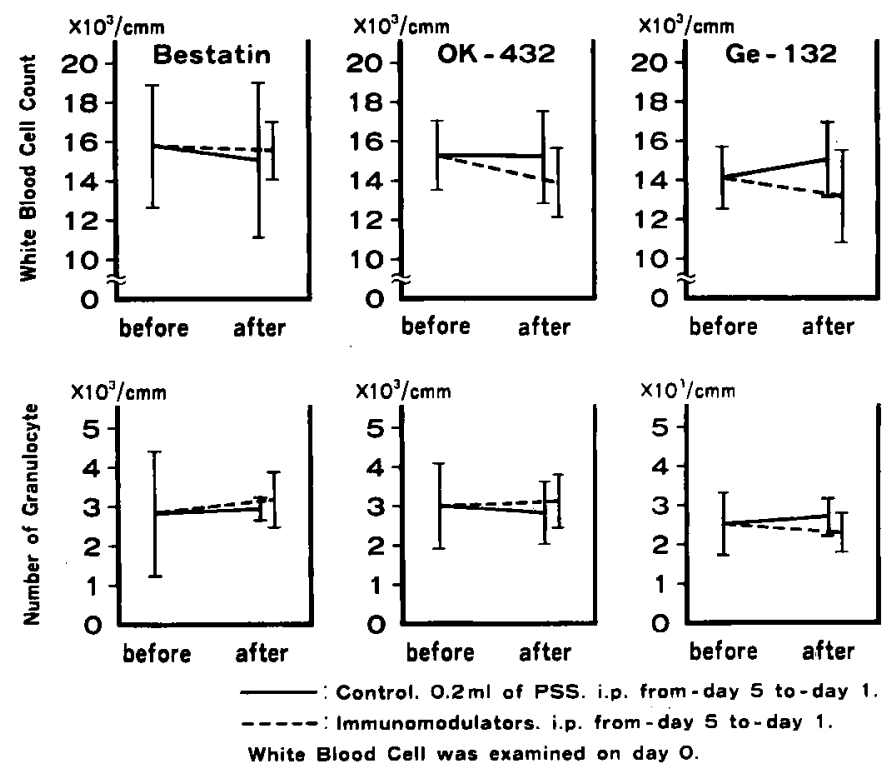

図 1 末梢白血球数に及ぼす Bestatin, OK-432，Ge-132 の影響 

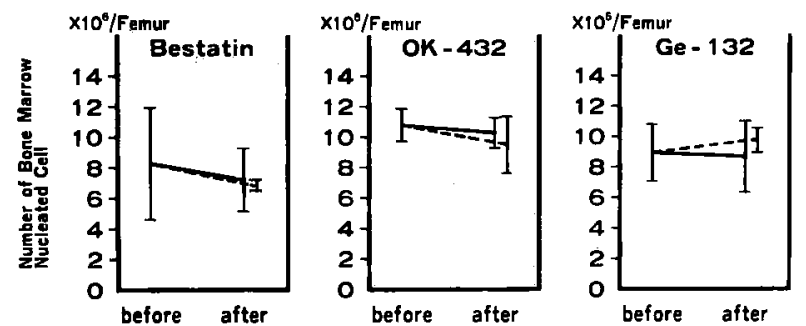

血抑制からの回復過程に及 ぼす Bestatin, OK-432, $\mathrm{Ge}-132$ の影響

第 1 項 末梢血液所見の検討 CPA 投与後の Bestatin, OK-432, $\mathrm{Ge}-132$ の白血球数, 顆粒球数に及ぼ す影響を経時的に検討した結果は図 3，

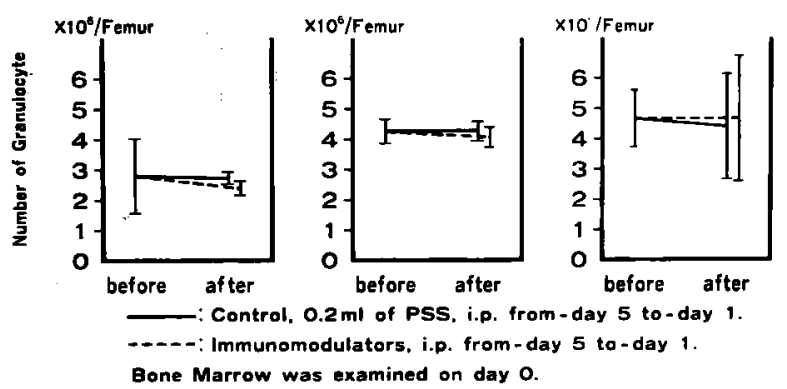

图2 骨能有核細胞数に及ぼす Bestatin, OK-432, $\mathrm{Ge}-132$ の影響

腫瘍性多糖体): $1.6 \mathrm{mg} / \mathrm{kg} / 0.2 \mathrm{ml}$ を, 後者に は生食水 $0.2 \mathrm{ml}$ を各々 1 回 i.p. 投与し，第 1 編 における検討と同様に放射線照射を行い，脾コ ロニー数の算定をday 8 にマウス屠殺後肉眼的 に行った，尚，各薬剤の比較検討は以下の式に てCFUs Index を算出し，比較した。

CFUs Index $=\frac{\text { 薬剤投与群のコロニー数 }}{\text { 生食水群のコロニー数の平均值 }}$

\section{実 繦}

第 1 節 $\mathrm{C}_{57} \mathrm{BL}$ マウス末梢白血球数並びに骨 髄有核細胞数 (NCC) に及ぼす Bestain, OK-432, Ge-132 の影響

Bestatin $(0.05 \mathrm{mg} / \mathrm{kg} / 0.2 \mathrm{ml}), \mathrm{OK}-432$ (40 $\mathrm{KE} / \mathrm{kg} / 0.2 \mathrm{ml}), \mathrm{Ge}-132(40 \mathrm{mg} / \mathrm{kg} / 0.2 \mathrm{ml}) の$ 各薬剤を 5 日間連日i.p. 投与し, 投与前後の末 梢白血球数並びに顆粒球数（桿状核数十分節核 球)の変化を検討した．その結果は図 1 に示 す如くで, 各群とも投与前後において有意の差 が認められなかった。また，各薬削の NCCに 及ぼす影響について検討したが，図 2 に示方如 くNCC，骨觬内顆粒球数とも投与前後に有意 の変化は認められなかった.

第 2 節 $\mathrm{C}_{57} \mathrm{BL}$ マウスにおける CPA 誘発造
$4 ， 5$ に示す如くで，まず白血球数の 変動についてみると day 3 で各群とも 最低值を示し，その後 day 5，7，9 の末梢白血球数は Bestatin 群で ( 9.0 $\pm 2.9) \times 10^{3} / \mathrm{cmm},(17.7 \pm 3.8) \times 10^{3} /$ $\mathrm{cmm},(17.1 \pm 4.2) \times 10^{3} / \mathrm{cmm}$ [生食水 群 $(6.7 \pm 2.6) \times 10^{3} / \mathrm{cmm},(10.7 \pm 3.6)$ $\left.\times 10^{3} / \mathrm{cmm},(12.8 \pm 4.7) \times 10^{3} / \mathrm{cmm}\right]$, 以下 OK-432 群では $(10.1 \pm 2.9) \times 10^{3} /$ $\mathrm{cmm},(15.9 \pm 0.9) \times 10^{3} / \mathrm{cmm},(20.1 \pm$ $5.8) \times 10^{3} / \mathrm{cmm}$ [生食水群 $(5.9 \pm 0.8)$ $\times 10^{3} / \mathrm{cmm},(12.3 \pm 1.2) \times 10^{3} / \mathrm{cmm}$, (13. $\left.3 \pm 2.8) \times 10^{3} / \mathrm{cmm}\right], \mathrm{Ge}-132$ 群で
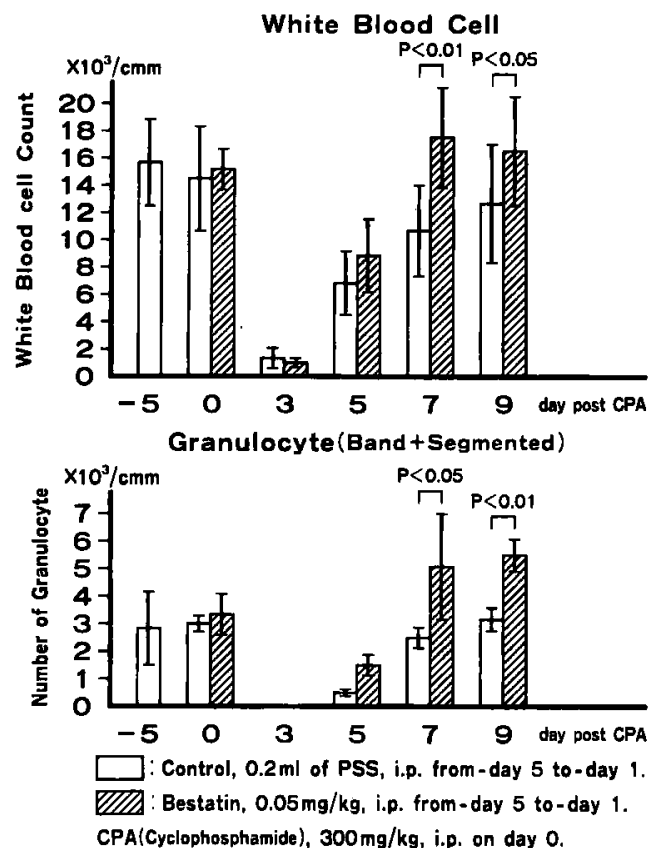

図 $3 \mathrm{CPA}$ 誘発造血抑制からの回復過程に及ぼす Bestain $の$ 影響 (末梢血) 

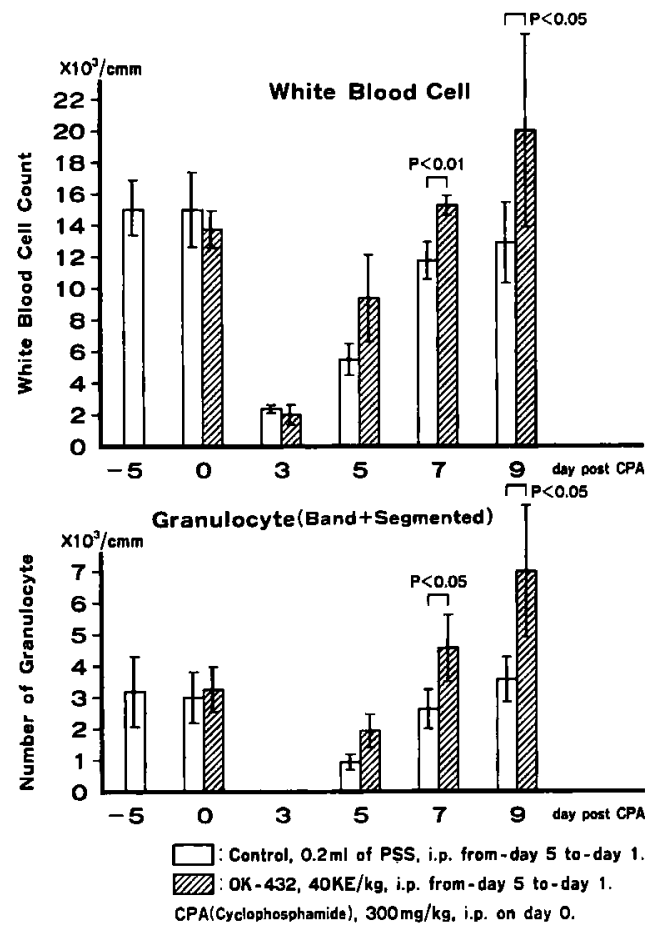

図 $4 \mathrm{CPA}$ 誘発造血抑制からの回復過程に及ぼす OK-432 の影響 (末梢血)

は $(6.2 \pm 0.4) \times 10^{3} / \mathrm{cmm},(11.3 \pm 1.2) \times 10^{3} / \mathrm{cmm}$, $(11.9 \pm 0.7) \times 10^{3} / \mathrm{cmm}$ [生食水群 $(6.4 \pm 0.5) \times$ $10^{3} / \mathrm{cmm},(11.0 \pm 2.1) \times 10^{3} / \mathrm{cmm},(12.1 \pm 2.2)$ $\times 10^{3} / \mathrm{cmm}$ と Bestatin 群, OK-432 群で末 梢白血球数の回復が有意 $(\mathrm{P}<0.05)$ に促進され ることが示された.

つぎに顆粒球数についても各群で検討したが， その結果は図 3，4，5 下段に示す如くで, Bestatin 群, OK-432 群で有意 $(\mathrm{P}<0.05)$ の 顆粒球回復促進効果が認められた。

第 2 項 骨髄所見の検討

Bestatin 群, OK-432 群, Ge-132 群の NCC, 骨髄内顆粒球数の変動は図 $6,7 ， 8$ に示す如 くでCPA 投与後の NCC は, day 3 で薬㣂投与 群，生食水群とも最低值を示したが, day 5 值 はBestatin 群 (8.71 \pm 0.69$) \times 10^{6}$, OK-432 群 $(10.77 \pm 2.05) \times 10^{6}, \mathrm{Ge}-132$ 群 $(7.56 \pm 1.62) \times$ $10^{6}$, day 7 值は各々 $(13.5 \pm 3.11) \times 10^{6},(11.6 \pm$ $1.21) \times 10^{6},(8.14 \pm 1.48) \times 10^{6}$, day 9 值は各々 $(15.8 \pm 4.25) \times 10^{6},(12.66 \pm 1.97) \times 10^{6},(10.24$
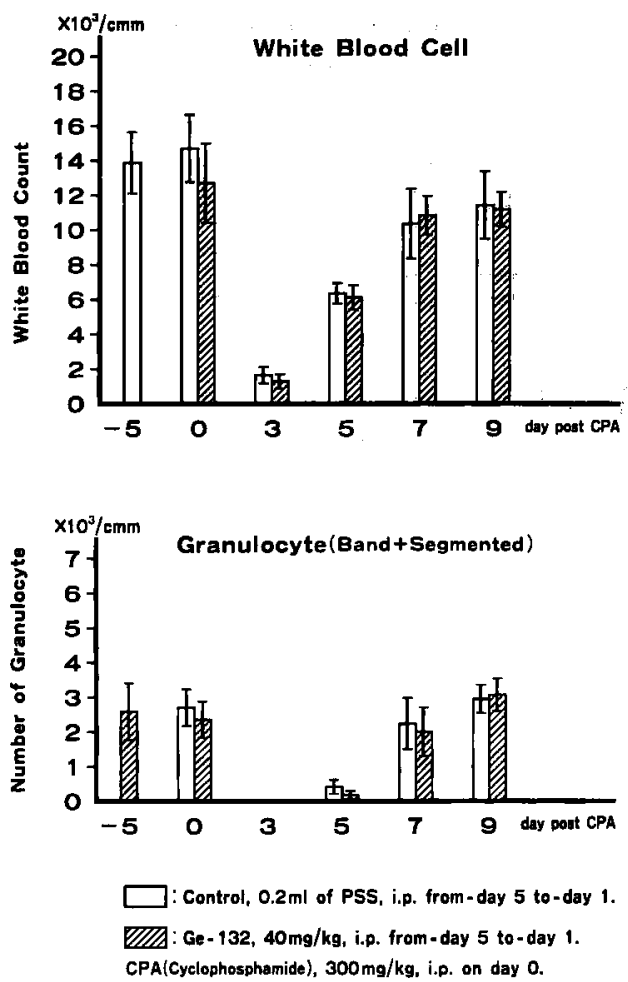

図 $5 \mathrm{CPA}$ 誘発造血抑制からの回復過程に及ぼす $\mathrm{Ge}-132$ の影響 (末梢血)

土2.06) $\times 10^{6}$ と Bestatin群, OK-432 群ともに 骨觬抑制からの回復が有意 $(P<0.05)$ に促進さ れることが示された。

尚，骨䯣内顆粒球数 (桿状核球十分節核球) の 推移は，図6，7，8 下段に示す如くで Bestatin 群, OK-432 群ともに day 5 以後顆粒球数 の回復促進が認められた。

第 3 節 CPA 誘発造血抑制からの回復過程に 及ぼす Bestatin, OK-432, Ge-132 の比較検討

Bestatin, OK-432, Ge-132 の CPA 誘発造 血抑制からの白血球数回復過程に及ぼす影響を 比較すると図 9 に示す如くで, day $0 ， 3 ， 5$ で は各群間に著明な差は認められなかったが， day 7 での薬郕投与前值に対する増加率は Bestatin

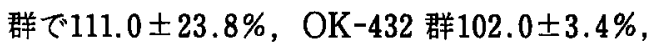
と生食水群に比し両群とも有意 $(\mathrm{P}<0.001)$ の 回復促進效果を示し day 9 では各々 $107.0 \pm 26.1$ $\% ， 133.0 \pm 41.1 \%$ とOK-432 群で回復促進効果 

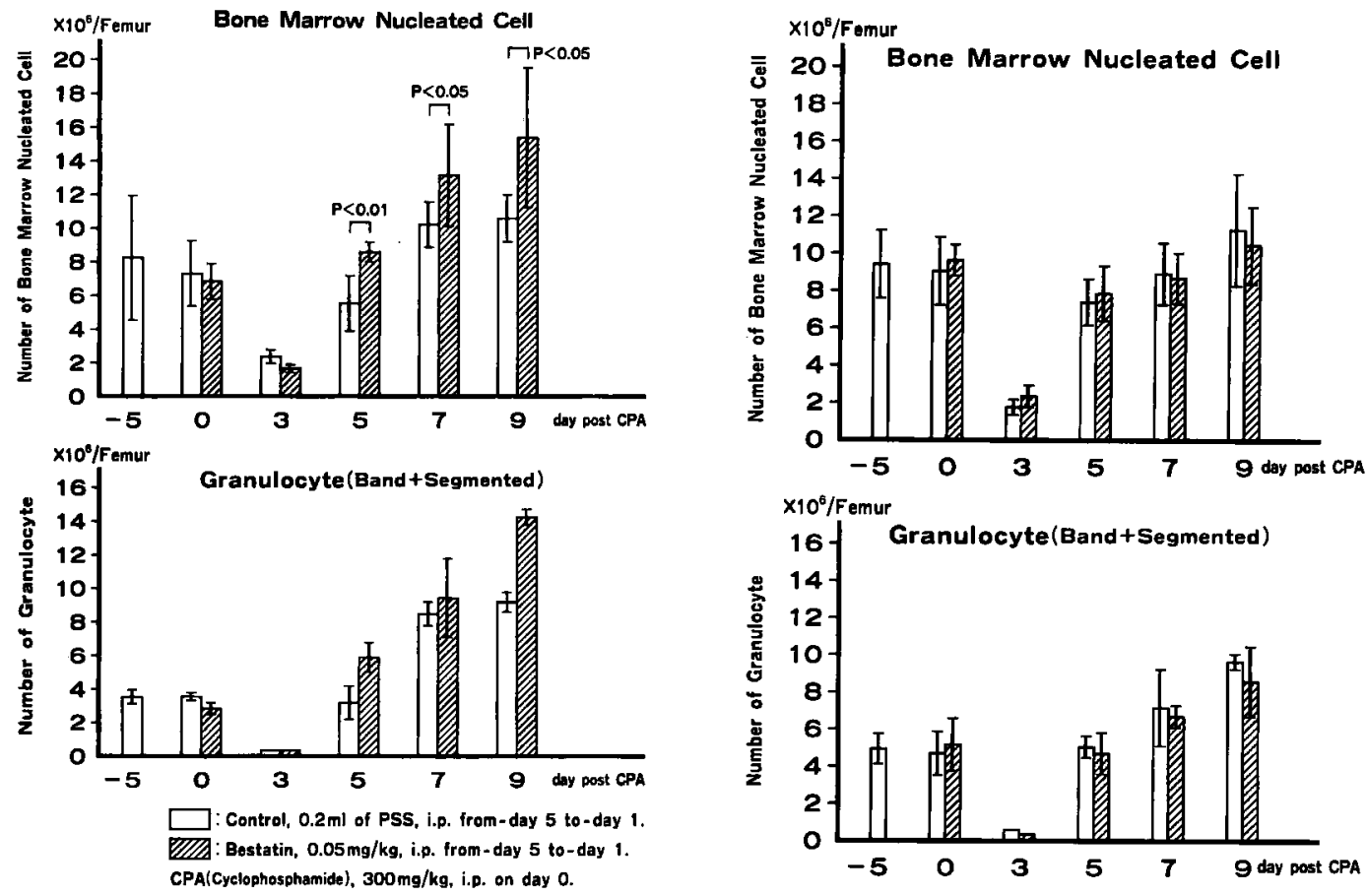

図 6 CPA 誘発造血抑制からの回復過程に及ぼす Bestatinの影響 (骨觬)
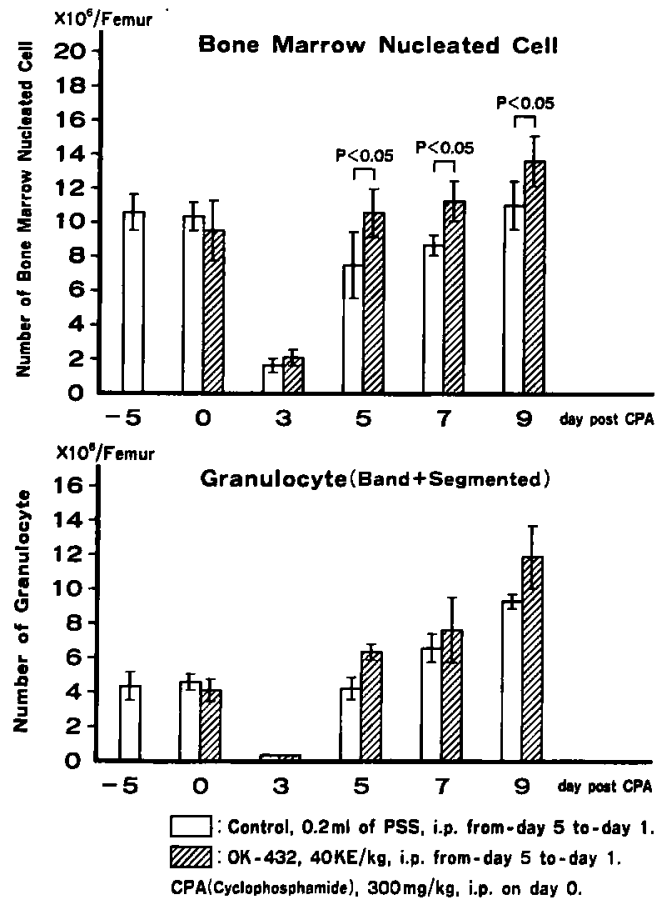

図7CPA 誘発造血抑制からの回復過程に及ぼす OK-432 の影響（骨夠）

のつよい傾向が認められた，尚，最低値到達日 数あるいは最低值からの回復日数ではBestatin群， OK-432 群間には差は認められなかった。

第 4 節 $\mathrm{C}_{57} \mathrm{BL}$ マウス autologous CFUsに 及ぼす OK-432, Bestatin, Ge-132, Lentinan $の$ 比較検討

OK-432, Bestatin, Ge-132, Lentinan の autologous CFUs への影響を比較した結果は 図10に示す如くで各群における CFUs Index は

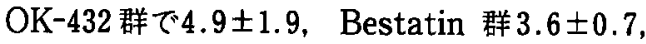
Lentinan 群 $2.3 \pm 1.2, \mathrm{Ge}-132$ 群 $1.3 \pm 0.8$ と autologous CFUs 増加作用は OK-432 $\geqq$ Bestatin $>$ Lentinan $=\mathrm{Ge}-132$ の傾向にあることが 示された。

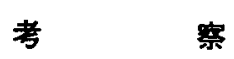

すでに周知の如く, 癌化学療法に随伴する正 常組織への影響，なかでも造血抑制による末梢 好中球減少は致死的感染症を誘発することから， 


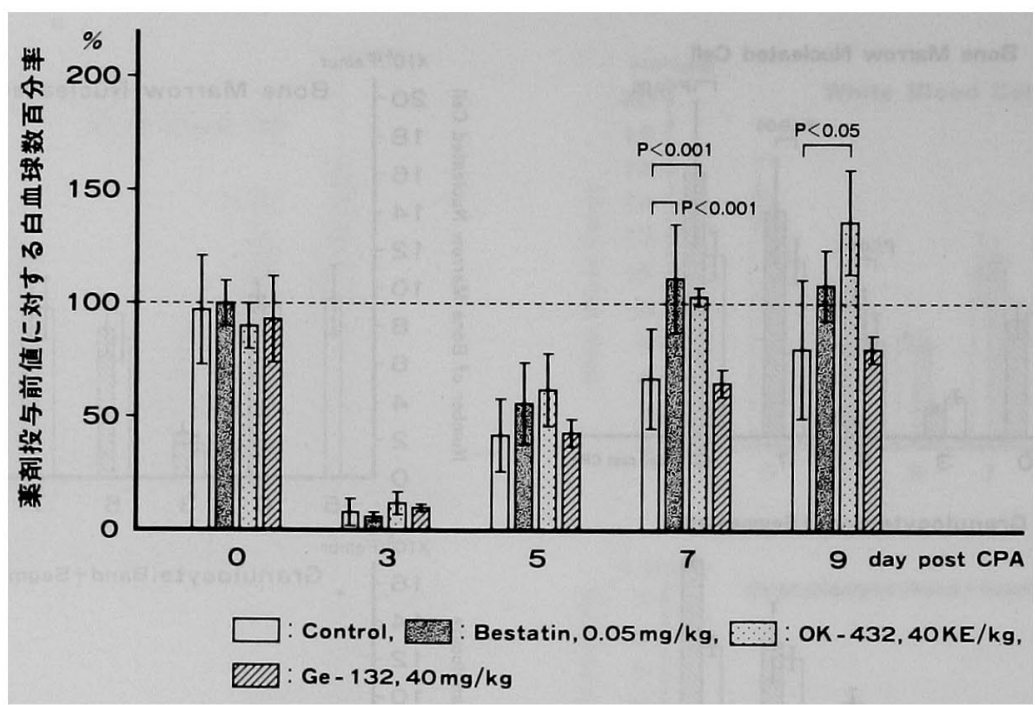

図 9 各薬片のCPA 誘発造血抑制からの回復過程に及ぼす影響の比較

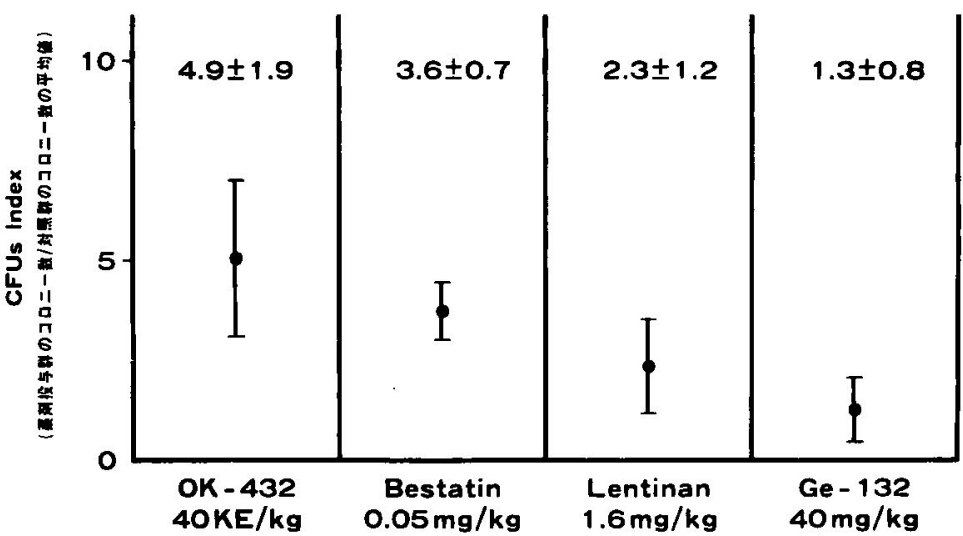

OK- 432 vs Bestatin : NS, OK -432 vs Lentinan : $p<0.05$,

OK- 432 vs Ge-132:p<0.005, Bestatin vs Lentinan : $p<0.05$,

Bestatin vs Ge $-132: p<0.005$, Lentinan vs Ge -132 : NS,

NS: Not Significant

図10 マウス autologous CFUsに及ぼす各薬戍の影響とその比較

その施行に対する limiting factorの一つとし て臨床上問題とされている. 感染症は急性白血 病をはじめとする造血器腫瘍はもとより固型腫 痬においても直接死因の第1位を占め ${ }^{9-13)}$, com- $^{-}$ promized host を基盤とした起炎菌の特殊性か $ら$ opportunistic infection とされているもの であるが, 臨床的に極めて難治性であり本症に 対する予防法あるいは治療法の確立が要求され ている1)。すでに予防対策としては非吸収性抗 生剂の経口投与, 含嗽，吸入等に加え， clean wall unit の使用など無菌室療法が，また治療
としては各種抗菌性抗生物質療法 ${ }^{2)}$, 顆粒球輸 注 ${ }^{14)}$ などが評価されているが, 化学療法後何ら かの方法によって骨剈遀造血能を賦活化し，好中 球减少を軽減するかあるいはその回復を促進さ せるかその検討は感染症予防対策のひとつとし てのみならず比較的長期に亘る宽解維持 - 強化 療法をより効果的に行うためにも必要とされる のではないかと考えられる.

近年, 各種免疫賦活郕の造血能賦活効果が注 目され OK-432 15, 16), Ge-132 17), Lithium carbonate ${ }^{18,19)}$, Corynebacterium parvum ${ }^{20)}$, 
$\mathrm{BCG}^{21)}$ 等の効果が検討されているが，その検討 はこれら薬剤の多面的生物学的活性を明らかに することが主たる目的とされ，癌化学療法ある いは放射線療法下での影響を目的とした前臨床 試験は少なく，その比較検討はより効果的な薬 郕選択に際しひとつの指標を提供するものでは ないかと考えられる. 今回著者は以上の観点に たち, 主にOK-432, Bestatin, Ge-132のCPA 誘発造血抑制からの回復過程に及ぼす影響とマ ウス autologous CFUsに及ぼす影響を比較検 討したわけであるが，CPA 誘発造血抑制からの 回復過程に及ぼす影響は Bestatin と OK-432 の両薬用間には有意差は認められなかったもの の図 9 の如く day 7 では Bestatin, OK-432 共 に生食水群に比し有意 $(\mathrm{P}<0.001)$ に回復促進 効果を示すことが認められた。ささらにマウス autologous CFUsにおけるOK-432, Bestatin, Lentinan, Ge-132の効果を CFUs Index を算 出し比較検討した結果, 図10の如く OK-432 Bestatin $>$ Lentinan $=\mathrm{Ge}-132$ の順に賦活効果 を示すことが確認された.

すでにこれまでOK-432の造血賦活効果につ いては諸家の報告がみられ ${ }^{15,16)}$, 教室の侬光 ${ }^{22,23)}$ は本剤の造血能賦活効果について基礎的, 臨床 的検討を行い急性非リンパ性白血病の寛解導入 㞠法に併用した結果, 感染予防効果は認められ なかったものの併用群で完全宽解到達期間が比 較的短く，かつ末梢血並びに骨髄顆粒球系細胞 の回復がより早期に認められたこと，さらにま た再寛解率は併用群で高く, 細胞性免疫能の保 持, 賦活効果の認められたことを報告している が, 再寛解率の高い要因については再寛解導入 療法に対する造血能の耐容性の影響も否定し得 ず，宽解時より強力な intensive postremission therapy が要求されている現在, その施 行に対し至適な背景を与えるものではないかと 考えられる. また $\mathrm{Ge}-132$ は分子量 339.34 の水 溶性有機ゲルマニウム化合物 ${ }^{24)}$ で, マウスにお けるInterferon (IFN) 誘起作用とそれによるマ クロファージ活性化作用, NK 細胞活性化作用 等が明らかにされ25)，麻生ら ${ }^{26)}$ は, DonorRecipient 間のCFUs assayにより本郕の造 血能賦活作用を認めているが, 著者の検討では
Ge-132 に有意の autologous CFUs 增加作用 を認めなかったが, 著者の実駼系は単一個体に よるものであり，実験系の違いではないかと考 えられる，尚，著者らは $\mathrm{Ge}-132$ の造血能賦活 作用を確認する目的で急性非リンパ性白血病の 寞解維持療法に本剂を併用したが，宽解期間， 生存期間，末梢好中球数の変動に関してはこれ まで有意差を認めるに至っていない5).

癌化学療法における造血㧕制問題はすでに述 べた宽解導入時の急性期的問題と維持・強化療 法施行中の慢性期的問題が存在し, 治㙩体系か らみたとき前者は入院治療, 後者は外来通院治 療において問題とされるが造血能賦活剒の選択 もその効果の面はもとよりこれら治療体系に則 した薬荗が用いられる必要があろう. 今回, CPA 誘発造血抑制, マウス autologous CFUs の両実験系において OK-432 と Bestatin がほ ぼ同等の造血能倵活作用を有することが明らか にされたが, OK-432 は現在筋注, 静注で投与 され,一方 Bestatin は社会生活を防げること なく連日投与が経口で可能であることからすれ ば維持・強化療法による造血抑制の慢性期的問 題に対する予防対策において Bestatin 投与に一 つの評価が与えられるかもしれない.

以上，投与ルートの異なる各種免疫賦活郕の 造血能賦活効果を検討したが, 宽解導入期のみ ならず維持・強化療法期を通じたこれら薬郕の 継続投与は抗腫場剤の骨髄抑制への耐容性を增 強することにより，寛解期間の延長ひいては治 癒への至適宿主状況を提供するものと考えられ， 今後治療体系に応じた薬剤の選択により䅡極的 かつ体系的な臨床応用が行われるべきであると 考えられる.

結

論

癌化学療法による造血抑制防止に関する研究 の一端とし, 細菌由来の免疫賦活剤である溶連 菌製剂 OK-432（筋注, 静注投与）と化学合成 物質である Bestatin (経口投与), 水溶性有機化 合物である Ge-132 (静注, 経口投与) の 3 郕 について CPA 誘発造血抑制への影響, マウス autologous CFUs への影響を比較検討した。 その結果, 
1) OK-432 並びに Bestatin は CPA 誘発造 血抑制からの回復過程において有意の顆粒球系 細胞の回復促進効果を示し, その比較において はOK-432に強い傾向がうかがわれた。また Ge-132にはその効果は認められなかった.

2 ) OK-432 並びにBestatinは, 放射線照射 後のマウス autologous CFUs を有意に増加させ, Lentinan, Ge-132 に比し CFUs Index が高く各 薬哓の造血能賦活度は OK-432 $\geqq$ Bestatin > Lentinan $=\mathrm{Ge}-132$ であった。

3 ) Bestatin は，OK-432 とほほ同等の造血 能賦活作用を有し，かつ連日経口投与が可能で あることから, 癌化学療法, とくに維持・強化 療法による慢性期的造血抑制への対策に際し， 一つの評価が与えられるものと考えられた.
今後寛解導入療法時のみならず維持・強化療 法を通じての免疫賦活剤の投与は抗腫瘍剛の骨 髄抑制への耐容性を増強することにより宽解期 間の延長ひいては治瘠への至適状況を提供する ものと考元られ，今後その積極的かつ体系的な 臨床応用が期待される.

尚, 本論文の要旨は第 42 回日本癌学会総会 (名古屋) にて発表した.

稿を終えるにあたり御指導，御校閲を睗った恩師 木村郁郎教授並びに御指導いただいた高橋 功講師, 岡山大学医療技術短期大学部喜多嶋康一教授に深甚 なる謝意を表します。

1. 木村郁郎, 高橋 功：感染予防のための化学療法. 制癌沜投与時. 臨床と研究 (1980) 62, 1447-1450.

2. 木村郁郎, 高橋 功：一抵抗減弱時の感染症一白血病. 総合臨床（1981）30，2135-2140.

3. Thatcher N, Honeybourne D, Wogstaff J, Caroll K B, Barber PV, Morrison J B and Crowther D : Moderate to high dose cyclophosphamide and intercalated Corynebacterium parvum in patients, with metastatic lung cancer. Br J Dis Chest (1984) 78, 89-97.

4. Poulliart P, Palagie T, Schwarzenberg L, Brugerie H, Lheritier J and Mathe G : Effect of BCG on hematopoietic stem cells : Experimental and clinical study. Cancer Immunol Immunother (1976) $1,63-169$.

5. 原 雅道, 高橋 功, 福本光宏, 稲垣登稳, 植田育寛, 入江誠治, 小田康広, 藤本修逸, 遠藤 裕, 大本 英次郎, 滝沢道弘, 内田耕三郎, 高岡和子, 厚井文一, 中田安成, 喜多嶋康一, 木村郁郎：急性非リンパ 性白血病における Ge-132 の使用経験。医学々薬学（1983） 9， 829-831.

6. Gordon MY, Aquado M and Blackett NM : Effect of BCG and Corynebacterium parvum on the hematopoietic precursor cells in continuously irradiated mice : Possible mechanisms of action in immunotherapy. Eur J Cancer (1977) 13, 229-233.

7. Foster RS, Macpherson BR and Browdie DA : Effect of Corynebacterium parvum on colony stimulating factor and granulocyte-macrophage colony formation. Cancer Res (1977) 37, 13491355.

8. 蕉田宜夫, 松井謙吾：OK-432 の造血幹細胞に対する作用。癌と化学療法（1980） 7, 111-115.

9. Bodey GP, Buckley M, Sathe YS and Freirich EJ : Quantitative relationships between circulating leukocytes and infection in patients with acute leukemia. Ann Int Med (1966) 64, 328-340.

10. 称垣治郎，小川一誠：抗生物質療法. 癌と化学療法（1981） 8，1368-1374.

11. Hersh EM, Bodey GP, Nies BA and Freireich E J : Causes of death in acute leukemia. JAMA (J Am Med Assoc) (1965) 193, 105-109.

12. Inagaki J, Rodriguez V and Bodey G P : Causes of death in cancer patients. Cancer (1974) 33, $568-573$. 
13. 正岡 徽：白血病における感染症とその対策．医学のあゆ (1984) 128，1026-1030.

14. 厚井文一, 原 雅道, 高岡和子, 足立富郎, 渡辺清一郎, 内田耕三郎, 重葴 誠, 高橋 功, 喜多嶋康一, 木村郁郎：急性白血病に併発した重症感染症に対する顆粒球輸注の臨床効果. 日本輸血学会雑誌（1981） 27, $516-520$.

15. Hiraoka A. Yamagishi M, Ohkubo T, Yoshida $\mathrm{Y}$ and Uchino H : In vitro effect of murineperitoneal exudate cells activated with a streptococcal preparation, OK-432, on hematopoietic stem cells. Acta hematol Jpn (1982) 45, 82-90.

16. 古沢新平, 間 栄, 槙原英夫, 齐藤憲治, 広瀬康二, 小松英昭, 宍戸英雄 : 溶連菌制剤 OK-432 の好中 球增等作用について，医学のおめ（1977）103，215-217.

17. 麻生 久, 渋谷恵美, 海老名卓三郎, 石田名香雄：Ge-132の骨剈道細胞に対する影響. 第 9 回ゲルマニウム 研究会誌 (1983) 22-27.

18. 清水俊一，倉辻忠俊，小島 正：リチウムの顆精球系骨解幹細胞コロニー形成への効果. 臨床血液（1982） 23, 305-308.

19. Lyman $G H$, Williams $C C$ and Preston D : The use of litium carbonate to reduce infection and leukopenia during systemic chemotherapy. N Engl J Med (1980) 302, 257-260.

20. Eliopoulos G, Andre S. Anagnou N P, Matsis C and Halpern B : Effect of Corynebacterium parvum on hemopoietic stem-cell kinetics. Int J Cancer (1979) 23, 114-118.

21. Ladisch S, Poplack DG and Bull J M : Acceleration of myeloid recovery from cyclophosphamideinduced leukopenia by pretreatment with Bacillus Calmette-Guerin. Cancer Res (1978) 38, 1049-1051.

22. 依光聖一：急性白血病寛解導入療法に関する研究 第 1 編 溶連菌製剤 OK-432の造血能に及ぼす影響並 びに化学療法における併用の意義について，岡山医誌（1985）97，277-287.

23. 低光聖一：急性白血病寛解導入療法に関する研究 第 2 編 急性白血病寛解導入療法における溶連菌製郕 OK-432 の評価. 岡山医誌 (1985) 97, 289-299.

24. Tsutsui M, Kakimoto N, Axtell D D, Oikawa $\mathrm{H}$ and Asai $\mathrm{K}$ : Crystal structure of "Carboxyethylgermanium Sesquioxide". J Am Chem Soc (1976) 98, 8287-8289.

25. 麻生 久, 鈴木富土夫, 山口高弘, 林 芳郎, 海老名卓三郎, 石田名香雄：有機ゲルマニウム化合物 $\mathrm{Ge}-132$ のマウスにおける IFN 誘起能と NK 細胞，マクロフォージ活性化作用. 癌と化学療法（1982）9，19761980.

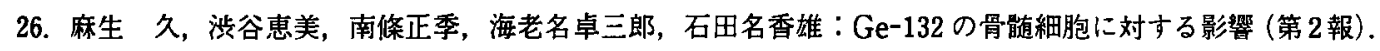
第10回ゲルマニウム研究会誌（1984）12-15. 


\title{
Experimental studies on the prevention of myelosuppression during cancer chemotherapy
}

Part II. Comparative sudies on the hemopoietic potentials of immunomodulators, Bestatin, streptococcal preparation OK-432 and Carboxyethylgermanium Sesquioxide (Ge-132), in mice

\author{
Kozaburo UCHIDA \\ Department of Internal Medicine, Okayama University Medical School \\ (Director: Prof. Ikuro Kimura)
}

\begin{abstract}
The hemopoietic potentials of three immunomodulators, Bestatin, OK-432 and Ge-132, were compared in terms of the effects of the drugs on the recovery from cyclophosphamide (CPA)induced myelosuppression, and on autologous CFUs in irradiated mice. The recovery from CPA-induced myelosuppression was significantly accelerated in mice pretreated with Bestatin or $\mathrm{OK} \mathbf{- 4 3 2}$ as compared to mice pretreated with Ge-132 or physiological saline. The effect of OK-432 was somewhat superior to that of Bestatin, but there were no significant differences in the days to nadir and in the days required for the recovery from nadir. Both Bestatin and OK-432 significantly increased the number of autologous CFUs in irradiated mice as compared to Ge-132 and Lentinan. Most chemotherapeutic schedules are divided into four therapeutic phases: induction, consolidation, maintenance and intensification. The last two phases were usually applied to outpatients; therefore, hemopoietic agents, such as Bestatin, which can be orally administrated, may be useful clinically for the prevention of chronic myelosuppression during maintenance and intensification chemotherapy.
\end{abstract}

